The Agriculturists 16(2): 01-14 (2018) ISSN 2304-7321 (Online), ISSN 1729-5211 (Print)

A Scientific Journal of Krishi Foundation

Indexed Journal

DOI: http://dx.doi.org/ 10.3329/agric.v16i02.40338

Impact Factor: 0.568 (GIF, 2015)

\title{
Variability, Heritability and Diversity Analysis for Some Morphological Traits in Basmati Rice (Oryza sativa L.) Genotypes
}

\author{
Nadia Akter*, Mohammad Zahidul Islam, Tonmoy Chakrabarty and \\ Mohammad Khalequzzaman \\ Genetic Resources and Seed Division, Bangladesh Rice Research Institute (BRRI), Gazipur, \\ Bangladesh \\ *Corresponding author and Email: nadia.akter21@yahoo.com
}

Received: 25 September 2018

Accepted: 25 December 2018

\begin{abstract}
The present study was conducted at the research farm of Bangladesh Rice Research Institute (BRRI), Gazipur, during July to December (T. Aman season) 2016 to identify potential genotypes and suitable traits of Basmati rice (Oryza sativa L.) germplasm for breeding programs. Twenty-six genotypes were evaluated in a randomized complete block design with three replications. All genotypes exhibited a wide and significant variation for 13 morphological traits. Genotypic and Phenotypic co-efficient of variation were the highest for number of filled grains per panicle and 1000-grain weight. Higher heritability was observed for flag leaf width, plant height, number of filled grains per panicle, 1000grain weight and yield per hill. Grain yield per hill was positively as well as significantly associated with number of filled grain per panicle and grain length. According to $D^{2}$ cluster analysis, 26 test genotypes were grouped into 5 clusters. Cluster IV was the largest consisting of 8 genotypes. The first two principal components of 13 traits accounted for about $41.06 \%$ of the total variation and indicated a wide variation among the genotypes. The selected best traits were the number of filled grains/panicle and 1000- grain weight which showed high heritability and high genetic advance. Therefore, these traits could be used as selection criteria for desired breeding materials. Moreover, the genotypes under cluster I, cluster II and cluster V might be selected for future hybridization programs.
\end{abstract}

Keywords: Genetic variability; heritability, correlation, path coefficients, character association, Basmati genotypes, yield and yield components.

\section{Introduction}

Basmati Rice (Oryza sativa L.) popularly known as 'scented pearl' is a natural gift exclusively to Indian sub-continent. It is a special type of aromatic rice known to the world for its extralong grains, pleasant and distinct aroma (Allam et al., 2015).

The Basmati fine rice and traditional aromatic rice have a great demand both in the national and international market (Mannan et al., 2012). In fact, aromatic long slender Basmati fine grain rice varieties are very popular in the world market (Yoshihashi, 2005). Traditional basmati rice varieties are very low yielding due to their poor harvest index, tendency to lodging and increasing susceptibility to foliar diseases; hence there is a need to develop new varieties combining the grain quality attributes of basmati with high yield potential (Amarawathi et al., 2008). 
Most of the aromatic rice varieties in Bangladesh are of locally adapted, photoperiod-sensitive, and grown during Aman season under rainfed lowland ecosystem. The income potential is higher with aromatic fine rice cultivation, since its cultivation does not usually require additional expenditures whereas, demand is very high in both the domestic and internal market (Islam et al., 2016).

Therefore, Basmati rice genotypes can be considered as an export item for Bangladesh after selecting the better performing genotypes with superior traits. Grain yield is dependent on many contributing characters as well as on the environmental influence. Association of different characters is essential to determine their contribution towards yield. The knowledge about genetic variability of yield contributing characters presents the possibilities of the scope of improvement of individual characters.

Furthermore, knowledge of heritability is essential for selection based improvement, as it indicates the extent of transmissibility of a character into future generations (Sabesan et al., 2009). Before placing a strong emphasis on breeding for yield improvement traits, the knowledge on the association between yield and yield attributes will enable the breeder in the improvement of yield. The correlation coefficient may also help to identify characters that have little or no importance in the selection program. The existence of correlation may be attributed to the presence of linkage or pleiotropic effect of genes or physiological and development relationship or environmental effect or in a combination of all (Oad et al., 2002). The grain yield is the primary target for improvement of rice productivity in both favourable and unfavourable environments from its present level. Keeping in view the above facts, the present investigation was undertaken to assess the genetic variability, heritability, correlation and diversity among yield and its contributing traits in 26 rice germplasm accessions under rainfed ecosystem.

\section{Materials and Methods}

\subsection{Experimental site, experimental design and plant material}

The study was conducted at research farm of Bangladesh Rice Research Institute (BRRI), Gazipur, from July to December (T. Aman season), 2016. Geographically, the place is located at about $24.00^{\circ} \mathrm{N}$ latitude and $90.25^{\circ} \mathrm{E}$ longitude with an elevation of 8.4 meters from the sea level and is characterized by subtropical climate. The soil of the experimental site was clay loam in texture. The study was laid out as a randomized complete block design (RCBD) with three replications. Twenty-six Basmati type genotypes were selected from BRRI genebank (Table 1).

\subsection{Transplantation and management practices} Sprouted seeds were sown in the seedbed. Thirty days-old seedlings were transplanted using single seedling per hill. Fertilizers were applied (a) 60:20:40:10 kg N: P: K: S per hectare. However, except $\mathrm{N}$, the other fertilizers were applied at final land preparation. Nitrogen was applied in three equal splits, at 15 days after transplanting (DAT), at 35 DAT, and just before flowering. Intercultural operations and pest control measures were done as and when necessary.

\subsection{Data collection}

Data were collected on flag leaf length $(\mathrm{cm})$, flag leaf width $(\mathrm{cm})$, culm diameter $(\mathrm{mm})$, days to flowering, number of effective tiller, plant height $(\mathrm{cm})$, panicle length $(\mathrm{cm})$, days to maturity, number of filled grains per panicle, grain length $(\mathrm{mm})$, grain breadth $(\mathrm{mm}), 1000$-grain weight $(\mathrm{g})$ and yield per hill $(\mathrm{g})$.

\subsection{Statistical analyses}

The analysis of variance and comparison of means were performed by Statistix10 software. Diversity analysis, i.e. cluster analysis and principal component analysis (PCA) was conducted by GENSTAT software (version 5.5). 
The genetic parameters, including the genotypic and phenotypic variance, the genotypic and phenotypic coefficient of variance, heritability (broad sense), and the expected genetic advance (GA) were calculated using the formula given by Burton and Devane (1953) and Johnson et al., (1955). Genetic advance in percent of mean was calculated by the formula of Comstock et al., (1952).
Simple correlations (Pearson) among yield contributing traits and correlation coefficient partitioning into components of direct and indirect effects by path coefficient analysis were accomplished by using $\mathrm{R}$ software (version 3.2.1). The genotypic and phenotypic correlations, biplot analysis for the first two principal components (PC1 and PC2) were done using META-R software (version 6.03) (Alvarado et. al., 2015).

Table 1. Name, accession number and origin of 26 basmati rice genotype

\begin{tabular}{llll}
\hline S1 No & Acc. No. & Genotype & Source/Origin \\
\hline 1 & 2517 & BASH MATI TAPL -90 & BRRI Genebank \\
2 & 2518 & BASH MATI TAPL -91 & BRRI Genebank \\
3 & 2519 & BASH MATI TAPL -92 & BRRI Genebank \\
4 & 2520 & BASH MATI TAPL -93 & BRRI Genebank \\
5 & 2521 & BASH MATI TAPL -94 & BRRI Genebank \\
6 & 2522 & BASH MATI TAPL -95 & BRRI Genebank \\
7 & 2523 & BASH MATI TAPL -96 & BRRI Genebank \\
8 & 2524 & BASH MATI TAPL -97 & BRRI Genebank \\
9 & 4488 & BASMATI (IRGC-3647) & India \\
10 & 4489 & BASMATI 370 (IRGC-3680) & India \\
11 & 4490 & BASMATI T3 (IRGC-6447) & India \\
12 & 4494 & BASMATI 370 (IRGC-10629) & India \\
13 & 4495 & BASMATI (IRGC-27782) & Pakistan \\
14 & 4496 & BASMATI NANOT 439 (IRGC-27788) & Pakistan \\
15 & 4497 & BASMATI PARDNR442 (IRGC27790) & Pakistan \\
16 & 4500 & BASMATI-1 (IRGC-27798) & Pakistan \\
17 & 4501 & BASMATI-107 (IRGC-27803) & Pakistan \\
18 & 4502 & BASMATI-134 (IRGC-27809) & Pakistan \\
19 & 4503 & BASMATI-372 (IRGC-27823) & Pakistan \\
20 & 4504 & BASMATI-372B (IRGC-27825) & Pakistan \\
21 & 4505 & BASMATI-375A (IRGC-27827) & Pakistan \\
22 & 4506 & BASMATI-376 (IRGC-27828) & Pakistan \\
23 & 4507 & BASMATI-377 (IRGC-27833) & Pakistan \\
24 & 4508 & BASMATI-406 (IRGC-27836) & Pakistan \\
25 & 4509 & BASMATI-433 (IRGC-27836) & Pakistan \\
26 & 4510 & BASMATI(BEGNI) (IRGC-53639) & India \\
\hline & & & \\
& & & \\
\hline
\end{tabular}




\section{Results and Discussion}

\subsection{Genetic variation study}

The range, mean, variance, coefficients of variation, heritability and the genetic advance of 13 characters are presented in Table 2.

According to the results, the phenotypic coefficient of variation (PCV) was higher than the genotypic coefficient of variation (GCV) for all the characters considered indicating the presence of environmental influence to some degrees in the phenotypic expression of characters. This finding was similar for all the traits observed in another study by Osman et al. (2012). GCV was the highest (84.58) for number of filled grains per panicle followed by 1000 grain weight (42.99) and plant height (40.74), indicating a higher degree of genetic variability among the basmati genotypes for these traits. PCV values were also higher for the above mentioned traits. High GCV and PCV for number of filled grains per panicle were also recorded by Mazid et al. (2013) as well as by Pandey and Anurag (2010). Heritability (broad sense) ranged from 81.93 to $99.93 \%$, which were relatively higher for almost all the traits studied except for number of effective tillers per hill and days to maturity. Hasan et al. (2011) also found similar results in case of effective tillers.

High heritability associated with high genetic advance were found in number of filled grains per panicle and 1000 grain weight, which indicated that the characters were simply inherited in nature and controlled by few major genes or possessed additive gene effects. The heritability estimates with low genetic advance were estimated for flag leaf width, grain breadth, and effective tiller. This implies that non additive gene action may be responsible for the expression of these traits.

Table 2. Estimation of genetic parameters of different quantitative characters in 26 Basmati rice landraces

\begin{tabular}{llllllllll}
\hline $\begin{array}{l}\text { Charac } \\
\text { ter }\end{array}$ & Mean & Range & $\mathrm{V}_{\mathrm{p}}$ & $\mathrm{V}_{\mathrm{g}}$ & $\mathrm{PCV}$ & $\mathrm{GCV}$ & $\mathrm{h}_{\mathrm{b}}^{2}$ & $\begin{array}{l}\mathrm{GA} \\
(5 \%)\end{array}$ & GAPM \\
\hline LL & 35.17 & $24.43-45.71$ & 21.71 & 21.23 & 12.49 & 12.35 & 97.80 & 7.20 & 19.30 \\
LW & 1.08 & $0.93-1.25$ & 3.35 & 3.34 & 1.74 & 1.71 & 99.93 & 2.88 & 2.70 \\
CD & 5.74 & $4.72-6.99$ & 0.28 & 0.26 & 4.55 & 4.52 & 98.74 & 0.80 & 7.10 \\
DF & 103.87 & $97.00-114.00$ & 21.97 & 20.84 & 3.62 & 3.53 & 94.86 & 7.03 & 5.43 \\
ET & 9.96 & $5.00-14.00$ & 5.05 & 4.13 & 1.44 & 1.31 & 81.93 & 2.91 & 1.87 \\
PH & 159.00 & $134.75-178.86$ & 111.52 & 110.43 & 40.94 & 40.74 & 99.02 & 16.52 & 64.05 \\
PL & 27.75 & $23.45-31.53$ & 4.94 & 4.47 & 12.54 & 11.93 & 90.52 & 3.18 & 17.94 \\
DM & 138.91 & $129.00-145.00$ & 13.94 & 12.04 & 35.58 & 33.06 & 86.32 & 5.09 & 48.53 \\
FG & 99.60 & $59.80-145.20$ & 480.07 & 478.71 & 84.70 & 84.58 & 99.72 & 34.52 & 133.45 \\
GL & 9.18 & $7.34-11.34$ & 5.10 & 4.83 & 3.48 & 3.39 & 94.67 & 3.38 & 5.21 \\
GB & 2.43 & $2.11-3.37$ & 0.07 & 0.06 & 2.48 & 2.43 & 96.61 & 0.37 & 3.78 \\
TGW & 21.04 & $13.50-28.40$ & 15.11 & 15.04 & 43.33 & 42.99 & 99.53 & 6.11 & 125.39 \\
Y & 11.50 & $5.94-18.32$ & 8.41 & 8.39 & 14.24 & 14.22 & 99.69 & 4.57 & 22.43 \\
\hline
\end{tabular}

$\mathrm{V}_{\mathrm{p}}=$ Phenotypic variance, $\mathrm{V}_{\mathrm{g}}=$ Genotypic variance, $\mathrm{PCV}=$ Phenotypic Coefficient of variation, $\mathrm{GCV}=$ Genotypic coefficient of variation, $\mathrm{h}_{\mathrm{b}}^{2}=$ Heritability (Broad sense), GA = Genetic advance, GAPM = Genetic advance in percent of mean.

( $\mathrm{LL}=$ Flag leaf length, $\mathrm{LW}=$ Flag leaf width, $\mathrm{CD}=$ Culm diameter, $\mathrm{DF}=$ Days to flowering, $\mathrm{ET}=$ Number of effective tiller, $\mathrm{PH}=\mathrm{Plant}$ height, $\mathrm{PL}=$ Panicle length, $\mathrm{DM}=$ Days to maturity, $\mathrm{FG}=\mathrm{Number}$ of filled grain per panicle, $\mathrm{GL}=\mathrm{Grain}$ length, $\mathrm{GB}=\mathrm{Grain}$ breadth, $\mathrm{TGW}=1000$-grain weight, $\mathrm{Y}=\mathrm{Yield}$ per hill) 


\subsection{Correlation coefficient study}

Pearson correlation analysis among yield and its contributing components are shown in Table 3. It revealed that 1000 grain weight possessed significant positive correlation with days to flowering, number of filled grain per panicle and grain breadth. For better understanding correlation coefficients are separated into the genotypic and phenotypic level (Table 4). The genotypic correlation coefficients in most cases were found higher than their phenotypic correlation coefficients indicating the genetic reason of association. In some cases, the phenotypic correlation coefficient was higher than genotypic correlation indicating the suppressing effect of the environment which modified the expression of the characters at phenotypic level. Effective tillers showed positive and significant relationship with culm diameter and days to flowering at both genotypic and phenotypic level.

In addition to that, days to flowering had positively significant association with days to maturity (Kumar et al., 2018), grain breadth and 1000 grain weight but significant negative association with panicle length. The aforesaid relationship was similar at both genotypic and phenotypic level. Filled grain per panicle was recorded with significant positive relationship with panicle length. However, thousand grain weight exhibited significant positive relationship with days to flowering, grain breadth and filled grain. Grain yield was positively associated with number of filled grains per panicle, grain length, thousand grain weight (Akter et al., 2018), flag leaf width and days to maturity. Association with number of filled grains per panicle and grain length was significant and rests are insignificant.

\subsection{Path analysis}

In correlation studies, with the increasing number of variables, the indirect association becomes complex and important. In such a situation, path coefficient analysis is useful to find out direct and indirect causes of associations. Path coefficient analysis permits a critical examination to specific factors acting to produce a given correlation and measures the relative importance of each factor. Path coefficient analysis (Table 5) revealed that number of filled grains per panicle and grain length possessed the highest positive effect on grain yield followed by thousand grain weight. This indicates that more filled grain in panicle is the highly reliable component of grain yield. Another important character with high direct effect on seed yield is panicle length which showed a positive direct effect on seed yield along with filled grains per panicle. Hence, number of filled grains per panicle should be given prior attention in rice improvement program because of their major influence on yield. This finding was in accordance with Hasan et al. (2010). Negative direct effect was observed for number of effective tillers/plant and plant height. The residual effect of the present study was 0.362 , indicating variables studied in the present investigation explained $64 \%$ of the variability in yield and therefore, other attributes besides the characters studied are contributing for grain yield per plant.

\subsection{Principal component analysis}

Eigen values (latent roots) of five principal component axes and percentage of total variation accounted for them obtained from the component analysis are presented in Table 6 . The result revealed that the first axis largely accounted for the variations observed among the genotypes $(23.47 \%)$ followed by the second axis $(17.59 \%)$. The first five axes accounted for about $77 \%$ of the total variations among the 13 characters describing 26 Basmati rice genotypes where only $41.06 \%$ variation was accounted for the first two axes. Islam et al., (2016) observed that the first nine axes accounted about $90 \%$ of the total variations by PCA in 113 aromatic and fine grain rice landraces. On the other hand, Akter et al. (2018) and Chakravorty et al. (2013) observed the contribution of $80.37 \%$ and $75.9 \%$ of the first five and four components, respectively to the total variation in rice. 
Table 3. Pearson correlation coefficient among yield and yield contributing characters in Basmati rice genotypes

\begin{tabular}{|c|c|c|c|c|c|c|c|c|c|c|c|c|}
\hline & LL & LW & $\mathrm{CD}$ & $\mathrm{DF}$ & ET & $\mathrm{PH}$ & PL & DM & FG & GL & GB & TGW \\
\hline LL & 1.000 & -0.026 & -0.324 & 0.219 & 0.099 & 0.009 & -0.181 & 0.005 & 0.018 & 0.344 & 0.043 & 0.019 \\
\hline LW & & 1.000 & -0.047 & 0.211 & 0.064 & 0.237 & $0.369 *$ & 0.301 & 0.305 & 0.233 & -0.106 & 0.215 \\
\hline $\mathrm{CD}$ & & & 1.000 & 0.276 & $0.613 * *$ & -0.013 & -0.159 & 0.158 & -0.042 & $-0.407 *$ & $0.465^{*}$ & 0.149 \\
\hline $\mathrm{DF}$ & & & & 1.000 & $0.502 * *$ & -0.076 & $-0.458 *$ & $0.569 * *$ & -0.178 & 0.011 & 0.437 * & $0.447^{*}$ \\
\hline ET & & & & & 1.000 & -0.021 & 0.063 & -0.297 & -0.097 & 0.290 & -0.356 & 0.126 \\
\hline $\mathrm{PH}$ & & & & & & 1.000 & 0.285 & $-0.398 *$ & -0.200 & -0.009 & 0.174 & 0.163 \\
\hline PL & & & & & & & 1.000 & -0.199 & $0.551 * *$ & 0.016 & -0.318 & -0.359 \\
\hline $\mathrm{DM}$ & & & & & & & & 1.000 & 0.129 & 0.085 & -0.089 & 0.205 \\
\hline FG & & & & & & & & & 1.000 & -0.146 & -0.356 & $0.397 *$ \\
\hline GL & & & & & & & & & & 1.000 & -0.347 & 0.036 \\
\hline GB & & & & & & & & & & & 1.000 & $0.396^{*}$ \\
\hline TGW & & & & & & & & & & & & 1.000 \\
\hline
\end{tabular}

$*, * *$ Significant at $5 \%$ and $1 \%$ levels, respectively.

( $\mathrm{LL}=$ Flag leaf length, $\mathrm{LW}=$ Flag leaf width, $\mathrm{CD}=\mathrm{Culm}$ diameter, $\mathrm{DF}=$ Days to flowering, ET= Number of effective tiller, $\mathrm{PH}=\mathrm{Plant}$ height, $\mathrm{PL}=$ Panicle length, DM=Days to maturity, $\mathrm{FG}=$ Number of filled grain per panicle, GL= Grain length, GB=Grain breadth, TGW=1000-grain weight, Y= Yield per hill) 
Table 4. Genotypic (G) and phenotypic (P) correlations among yield and yield contributing characters in Basmati rice genotypes

\begin{tabular}{|c|c|c|c|c|c|c|c|c|c|c|c|c|c|}
\hline Traits & & LL & LW & $\mathrm{CD}$ & DF & ET & $\mathrm{PH}$ & PL & $\mathrm{DM}$ & FG & GL & GB & TGW \\
\hline \multirow[t]{2}{*}{ LW } & $\mathrm{G}$ & -0.029 & & & & & & & & & & & \\
\hline & $\mathrm{P}$ & -0.028 & & & & & & & & & & & \\
\hline & $\mathrm{G}$ & -0.326 & -0.046 & & & & & & & & & & \\
\hline $\mathrm{CD}$ & $\mathrm{P}$ & -0.337 & -0.045 & & & & & & & & & & \\
\hline \multirow[t]{2}{*}{$\overline{\mathrm{DF}}$} & $\mathrm{G}$ & 0.228 & 0.241 & 0.285 & & & & & & & & & \\
\hline & $\mathrm{P}$ & 0.192 & 0.240 & 0.274 & & & & & & & & & \\
\hline \multirow[t]{2}{*}{ ET } & $\mathrm{G}$ & 0.113 & 0.110 & $0.611 * *$ & $0.517 * *$ & & & & & & & & \\
\hline & $\mathrm{P}$ & 0.145 & 0.060 & $0.593 * *$ & $0.457 *$ & & & & & & & & \\
\hline \multirow[t]{2}{*}{$\mathrm{PH}$} & $\mathrm{G}$ & 0.028 & 0.257 & -0.013 & -0.080 & -0.061 & & & & & & & \\
\hline & $\mathrm{P}$ & 0.027 & 0.225 & -0.035 & -0.196 & -0.056 & & & & & & & \\
\hline \multirow[t]{2}{*}{$\mathrm{PL}$} & $\mathrm{G}$ & -0.184 & $0.401 *$ & -0.164 & $-0.459 *$ & 0.049 & 0.288 & & & & & & \\
\hline & $\mathrm{P}$ & -0.209 & 0.360 & -0.176 & $-0.556^{* *}$ & 0.097 & 0.247 & & & & & & \\
\hline \multirow[t]{2}{*}{$\mathrm{DM}$} & $\mathrm{G}$ & 0.007 & 0.306 & 0.164 & $0.587 * *$ & -0.318 & $-0.428 *$ & -0.238 & & & & & \\
\hline & $\mathrm{P}$ & 0.004 & 0.275 & 0.153 & $0.566^{* *}$ & -0.278 & $-0.473 *$ & -0.255 & & & & & \\
\hline \multirow[t]{2}{*}{ FG } & $\mathrm{G}$ & 0.018 & 0.334 & -0.042 & -0.167 & -0.128 & -0.200 & $0.560 * *$ & 0.099 & & & & \\
\hline & $\mathrm{P}$ & 0.022 & 0.292 & -0.040 & -0.166 & -0.135 & -0.201 & $0.566^{* *}$ & 0.102 & & & & \\
\hline \multirow[t]{2}{*}{ GL } & $\mathrm{G}$ & $0.396^{*}$ & 0.273 & $-0.451^{*}$ & 0.003 & 0.354 & -0.010 & 0.024 & 0.108 & -0.162 & & & \\
\hline & $\mathrm{P}$ & 0.360 & 0.242 & $-0.405^{*}$ & 0.044 & 0.303 & -0.020 & 0.036 & 0.084 & -0.149 & & & \\
\hline \multirow[t]{2}{*}{ GB } & $\mathrm{G}$ & 0.045 & -0.129 & $0.467 *$ & $0.449 *$ & -0.347 & 0.174 & -0.326 & -0.075 & -0.356 & -0.385 & & \\
\hline & $\mathrm{P}$ & 0.042 & -0.108 & $0.464 *$ & $0.457 *$ & -0.336 & 0.168 & -0.329 & -0.079 & -0.353 & -0.346 & & \\
\hline \multirow[t]{2}{*}{ TGW } & $\mathrm{G}$ & 0.019 & 0.254 & 0.150 & $0.449 *$ & 0.129 & 0.163 & -0.367 & 0.216 & $0.398^{*}$ & 0.032 & $0.395^{*}$ & \\
\hline & $\mathrm{P}$ & 0.045 & 0.227 & 0.167 & $0.556 * *$ & 0.082 & 0.232 & -0.335 & 0.240 & $0.411^{*}$ & 0.016 & $0.410^{*}$ & \\
\hline \multirow[t]{2}{*}{$\mathrm{Y}$} & $\mathrm{G}$ & 0.045 & 0.269 & -0.081 & 0.140 & 0.137 & 0.036 & 0.079 & 0.137 & $0.441^{*}$ & $0.438 *$ & 0.135 & 0.268 \\
\hline & $\mathrm{P}$ & 0.042 & 0.232 & -0.083 & 0.138 & 0.134 & 0.030 & 0.075 & 0.131 & $0.442 *$ & $0.396^{*}$ & 0.133 & 0.278 \\
\hline
\end{tabular}

$*$ ** Significant at $5 \%$ and $1 \%$ levels, respectively.

( $\mathrm{LL}=$ Flag leaf length, $\mathrm{LW}=$ Flag leaf width, $\mathrm{CD}=\mathrm{Culm}$ diameter, $\mathrm{DF}=$ Days to flowering, $\mathrm{ET}=$ Number of effective tiller, $\mathrm{PH}=\mathrm{Plant}$ height, $\mathrm{PL}=$ Panicle length, $\mathrm{DM}=$ Days to maturity, $\mathrm{FG}=$ Number of filled grain per panicle, $\mathrm{GL}=\mathrm{Grain}$ length, GB=Grain breadth, TGW=Thousand grain weight, $Y=$ Yield per hill) 
Table 5. Path analysis showing direct and indirect effects of yield component on Basmati rice genotypes

\begin{tabular}{llllllllllllllll}
\hline & LL & LW & CD & DF & ET & PH & PL & DM & FG & GL & GB & TGW & Y \\
\hline LL & $\mathbf{0 . 1 2 0}$ & $\mathbf{- 0 . 0 0 7}$ & $\mathbf{0 . 0 1 2}$ & $\mathbf{0 . 0 0 1}$ & $\mathbf{- 0 . 0 0 9}$ & $\mathbf{- 0 . 0 0 4}$ & $\mathbf{- 0 . 1 3 2}$ & $\mathbf{0 . 0 0 1}$ & $\mathbf{- 0 . 0 1 6}$ & $\mathbf{0 . 0 6 9}$ & $\mathbf{0 . 0 0 7}$ & $\mathbf{0 . 0 0 2}$ & $\mathbf{0 . 0 4 5}$ \\
LW & -0.003 & $\mathbf{0 . 2 5 4}$ & 0.002 & 0.001 & -0.006 & -0.101 & 0.269 & 0.026 & -0.274 & 0.047 & -0.017 & 0.024 & 0.222 \\
CD & -0.039 & -0.012 & $\mathbf{- 0 . 0 3 8}$ & 0.002 & 0.057 & 0.005 & -0.116 & 0.014 & 0.038 & -0.082 & 0.074 & 0.017 & -0.080 \\
DF & 0.026 & 0.054 & -0.011 & $\mathbf{0 . 0 0 6}$ & 0.047 & 0.032 & -0.334 & 0.049 & 0.159 & 0.002 & 0.070 & 0.050 & 0.151 \\
ET & 0.012 & 0.016 & 0.023 & -0.003 & $\mathbf{- 0 . 0 9 4}$ & 0.009 & 0.046 & -0.026 & 0.087 & 0.058 & -0.057 & 0.014 & 0.087 \\
PH & 0.001 & 0.060 & 0.001 & 0.001 & 0.002 & $\mathbf{- 0 . 4 2 5}$ & 0.208 & -0.034 & 0.179 & -0.002 & 0.028 & 0.018 & 0.036 \\
PL & -0.022 & 0.094 & 0.006 & -0.003 & -0.006 & -0.121 & $\mathbf{0 . 7 2 9}$ & -0.017 & -0.494 & 0.003 & -0.051 & -0.040 & 0.079 \\
DM & 0.001 & 0.077 & -0.006 & 0.003 & 0.028 & 0.169 & -0.145 & $\mathbf{0 . 0 8 6}$ & -0.116 & 0.017 & -0.014 & 0.023 & 0.123 \\
FG & 0.002 & 0.078 & 0.002 & -0.001 & 0.009 & 0.085 & 0.402 & 0.011 & $\mathbf{0 . 8 9 7}$ & -0.029 & -0.057 & -0.045 & $0.441 *$ \\
GL & 0.041 & 0.059 & 0.016 & 0.001 & -0.027 & 0.004 & 0.012 & 0.007 & 0.131 & $\mathbf{0 . 2 0 2}$ & -0.055 & 0.004 & $0.393 *$ \\
GB & 0.005 & -0.027 & -0.018 & 0.003 & 0.033 & -0.074 & -0.232 & -0.008 & 0.319 & -0.070 & $\mathbf{0 . 1 6 0}$ & 0.044 & 0.136 \\
TGW & 0.002 & 0.055 & -0.006 & 0.003 & -0.012 & -0.069 & -0.262 & 0.018 & 0.356 & 0.007 & 0.063 & $\mathbf{0 . 1 1 2}$ & 0.268 \\
\hline
\end{tabular}

Residual Effect=0.362904

$*$ **Significant at $5 \%$ and $1 \%$ levels, respectively.

(LL= Flag leaf length, $\mathrm{LW}=$ Flag leaf width, $\mathrm{CD}=\mathrm{Culm}$ diameter, $\mathrm{DF}=$ Days to flowering, ET= Number of effective tiller, $\mathrm{PH}=\mathrm{Plant}$ height, $\mathrm{PL}=$ Panicle length, $\mathrm{DM}=$ Days to maturity, $\mathrm{FG}=$ Number of filled grain per panicle, GL= Grain length, GB=Grain breadth, TGW=1000-grain weight, Y= Yield per hill) 
Table 6. Latent roots (Eigen values) and their variation in five quantitative characters in 26 Basmati rice landraces

\begin{tabular}{llll}
\hline Principal component axes & Latent roots & \% Variation & Cumulative \% of variation \\
\hline I & 3.052 & 23.47 & 23.47 \\
II & 2.287 & 17.59 & 41.06 \\
III & 1.912 & 14.71 & 55.77 \\
IV & 1.650 & 12.69 & 68.46 \\
V & 1.114 & 8.57 & 77.03 \\
\hline
\end{tabular}

Biplot. Location: 1

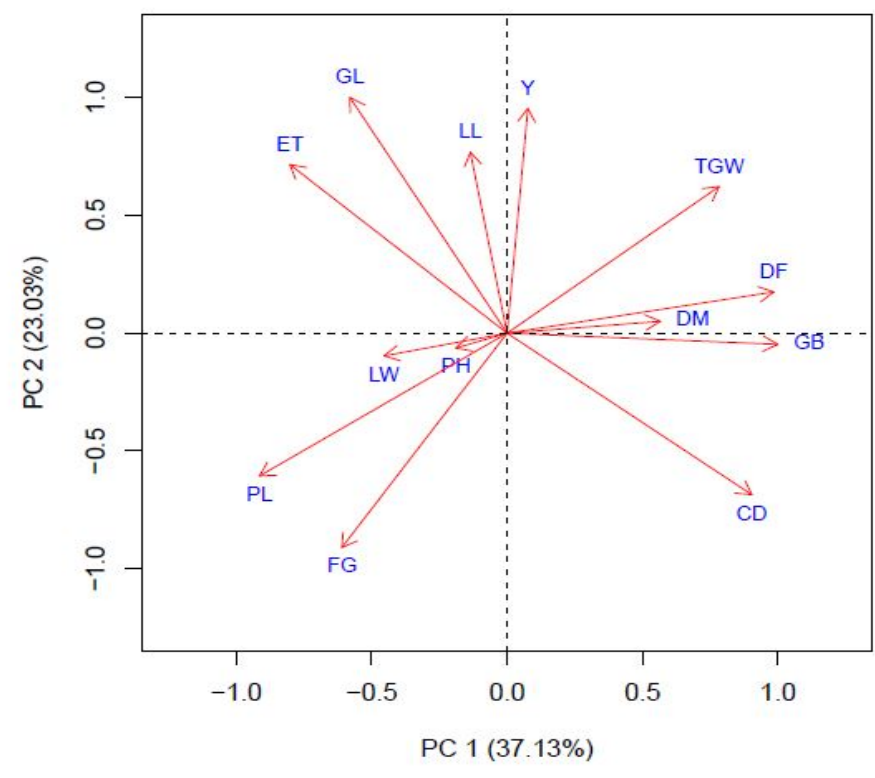

Figure1. Biplot analysis for the first two principal component PC1 and PC2

( $\mathrm{LL}=$ Flag leaf length, $\mathrm{LW}=$ Flag leaf width, $\mathrm{CD}=$ Culm diameter, $\mathrm{DF}=$ Days to flowering, $\mathrm{ET}=$ Number of effective tiller, $\mathrm{PH}=\mathrm{Plant}$ height, $\mathrm{PL}=$ Panicle length, $\mathrm{DM}=$ Days to maturity, $\mathrm{FG}=\mathrm{Number}$ of filled grain per panicle, $\mathrm{GL}=$ Grain length, $\mathrm{GB}=$ Grain breadth, TGW=1000-grain weight, Y= Yield per hill)

Biplot analysis indicates that yield is strongly influenced by flag leaf length, grain length, number of effective tiller, 1000 grain weight, days to flowering and days to maturity as those lines with arrow are close to yield. In addition to that, the first two principal component PC1 and PC2 accounted for $37.13 \%$ and $23.03 \%$ variation, respectively and combinedly they contribute for $41.06 \%$ of total variation. 
Based on morphological diversity, twenty-six Basmati genotypes were grouped into five clusters (Table 7). Islam et al., (2014), Akter et al., (2016) and Ahmed et al. (2010) reported six clusters each. Besides that, Islam et al. (2017) and Siddique et al. (2013) reported five clusters each in their experiment with rice genotypes. The distribution pattern revealed maximum number of genotypes in cluster IV (eight genotypes) followed by six genotypes in cluster I and four in cluster II, III and V.

Intra- and inter cluster distances are presented in Table 8 . There were no considerable variations in intra cluster distances which ranged from 0.54 in cluster II to 0.88 in cluster I indicating homogeneous nature of the genotypes within the cluster. The highest intra cluster distance was computed for cluster I (0.88) which was comprised of six genotypes followed by cluster
$\mathrm{V}$ (0.66) with four genotypes. The genotypes under cluster I (with the highest intra cluster mean) were heterogeneous in some extent and genotypes under cluster II (with the lowest intra cluster mean) were comparatively homogenous.

The inter cluster distances ranged from 1.67 to 5.93 indicated a poor genetic diversity among the genotypes. Similar results were found by Salgotra et al., (2017). Regarding inter-cluster distance, cluster II showed the maximum genetic distance (5.93) from cluster $\mathrm{V}$ followed by cluster III (5.46) from cluster II and so on. Cluster V produced the highest inter-cluster distances $\left(\mathrm{D}^{2}\right.$ values) with all other clusters showing considerable diversity between the genotypes and the genotypes in these clusters could be used as parents in future hybridization programme.

Table 7. Distribution of 26 Basmati rice genotypes into five clusters

\begin{tabular}{|c|c|c|c|}
\hline Cluster & $\begin{array}{l}\text { Number of } \\
\text { genotypes }\end{array}$ & $\begin{array}{l}\% \text { of total } \\
\text { genotypes }\end{array}$ & Name of genotypes \\
\hline I & 6 & 23.09 & $\begin{array}{l}\text { BASH MATI TAPL-94, BASH MATI TAPL-97, } \\
\text { BASMATI T3 (IRGC-6447), BASMATI-134 (IRGC- } \\
\text { 27809), BASMATI-375A (IRGC-27827), BASMATI- } \\
406 \text { (IRGC-27836) }\end{array}$ \\
\hline II & 4 & 15.38 & $\begin{array}{lccc}\text { BASH } & \text { MATI } & \text { TAPL-92, BASMATI (IRGC-27782), } \\
\text { BASMATI-1 } & \text { (IRGC-27798), BASMATI } & \text { (BEGNI) } \\
\text { (IRGC-53639) } & & \end{array}$ \\
\hline III & 4 & 15.38 & $\begin{array}{l}\text { BASH MATI TAPL-90, BASH MATI TAPL-93, } \\
\text { BASMATI NANOT } 439 \text { (IRGC-27788), BASMATI-107 } \\
\text { (IRGC-27803) }\end{array}$ \\
\hline IV & 8 & 30.77 & 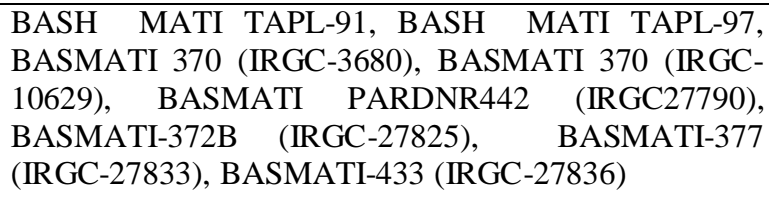 \\
\hline $\mathrm{V}$ & 4 & 15.38 & $\begin{array}{l}\text { BASH MATI TAPL-95, BASMATI (IRGC-3647), } \\
\text { BASMATI-372 (IRGC-27823), BASMATI-376 (IRGC- } \\
\text { 27828) }\end{array}$ \\
\hline
\end{tabular}


Table 8. Intra (bold) and inter-cluster distances $\left(\mathrm{D}^{2}\right)$ among 26 Basmati rice landraces

\begin{tabular}{llllll}
\hline Cluster & I & II & III & IV & V \\
\hline I & $\mathbf{0 . 8 8 9 6}$ & 2.791 & 2.363 & 1.669 & 3.305 \\
II & & $\mathbf{0 . 5 4 8 0}$ & 5.464 & 2.584 & 5.926 \\
III & & & $\mathbf{0 . 6 5 0 4}$ & 2.256 & 4.560 \\
IV & & & $\mathbf{0 . 6 0 6 8}$ & 4.379 \\
V & & & & & $\mathbf{0 . 6 6 2 1}$ \\
\hline
\end{tabular}

Table 9. Cluster means for 13 characters in Basmati rice genotypes

\begin{tabular}{llllll}
\hline Characters & I & II & III & IV & V \\
\hline LL & $33.22(\mathrm{~L})$ & 36.90 & $42.02(\mathrm{H})$ & 33.61 & 33.42 \\
LW & 1.07 & $1.12(\mathrm{H})$ & $1.00(\mathrm{~L})$ & 1.10 & 1.04 \\
CD & $6.19(\mathrm{H})$ & 5.80 & $5.33(\mathrm{~L})$ & 5.74 & 5.59 \\
DF & $108.67(\mathrm{H})$ & 106.50 & 103.00 & 101.67 & $101.00(\mathrm{~L})$ \\
ET & 9.00 & $8.88(\mathrm{~L})$ & 11.00 & 10.17 & $11.14(\mathrm{H})$ \\
PH & 159.30 & 162.67 & $140.12(\mathrm{~L})$ & 154.93 & $163.57(\mathrm{H})$ \\
PL & $25.53(\mathrm{~L})$ & 27.65 & 26.21 & $29.93(\mathrm{H})$ & 27.37 \\
DM & $140.00(\mathrm{H})$ & 139.75 & 138.50 & 139.00 & $137.00(\mathrm{~L})$ \\
FG & 94.50 & 102.95 & 92.50 & $131.62(\mathrm{H})$ & $85.40(\mathrm{~L})$ \\
GL & 9.29 & 9.12 & $9.68(\mathrm{H})$ & $9.05(\mathrm{~L})$ & 9.17 \\
GB & $2.78(\mathrm{H})$ & 2.41 & $2.23(\mathrm{~L})$ & 2.34 & 2.42 \\
TGW & $25.82(\mathrm{H})$ & $17.95(\mathrm{~L})$ & 18.21 & 19.03 & 21.88 \\
Y & $15.15(\mathrm{H})$ & $10.39(\mathrm{~L})$ & 13.85 & 10.77 & 11.16 \\
\hline
\end{tabular}

(LL= Flag leaf length, $\mathrm{LW}=$ Flag leaf width, $\mathrm{CD}=$ Culm diameter, $\mathrm{DF}=$ Days to flowering, $\mathrm{ET}=$ Number of effective tiller, $\mathrm{PH}=\mathrm{Plant}$ height, $\mathrm{PL}=$ Panicle length, $\mathrm{DM}=$ Days to maturity, $\mathrm{FG}=\mathrm{Number}$ of filled grain per panicle, GL= Grain length, GB=Grain breadth, TGW=1000-grain weight, Y= Yield per hill)

The highest cluster means for yield, 1000 grain weight, culm diameter, days to flowering and grain breadth were obtained from cluster I (Table 9). The highest panicle length and filled grains per panicle were found in cluster IV. In addition to that, tallest plants, highest number of effective tillers along with shortest days to flowering and days to maturity were observed in cluster V. Furthermore, cluster III was characterized with the lowest cluster means for flag leaf width, culm diameter, plant height and grain breadth whereas possessed highest cluster means for flag leaf length and grain length. Cluster II had no highest class mean value other than for flag leaf 
Akter et al. /The Agriculturists 16(2): 1-14 (2018)

width. Moreover, the cluster showed lowest mean values for number of effective tiller, 1000 grain weight and ultimately resulted in lowest yield.

Cluster means for the characters studied revealed that the maximum desirable characters were accumulated in cluster I and as a result higher grain yield (15.15 g/hill) was obtained in this cluster. However, considering the yield, 1000 grain weight, crosses involving cluster I and cluster II may exhibit high heterosis for yield. Again, considering growth duration and number of effective tiller, crosses between cluster I and $\mathrm{V}$ may exhibit higher heterosis for earliness and effective tiller.

It is assumed that a cross combination between parents of most divergent clusters will exhibit maximum heterosis. The objective of breeding is not only high heterosis but also to achieve a high level of yield and reducing the life duration. In the present study the maximum distances existed between cluster II and V. However, considering the cluster means and inter-cluster distances crosses between the genotypes of cluster I and cluster II, cluster I and cluster V would exhibit high heterosis as well as higher level of yield potential. So, based on this result, the genotypes under cluster I, cluster II and cluster V might be selected for hybridization program.

\section{Conclusions}

The highest GCV was recorded for number of filled grains per panicle followed by 1000 grain weight and plant height. High heritability associated with high genetic advance was observed in number of filled grains per panicle and 1000 grain weight. Moreover, grain yield had significant correlation with number of filled grains per panicle and grain length. The cluster analysis placed 26 Basmati rice genotypes into five groups. Considering the highest inter cluster distance, parent materials selected from cluster I, cluster II and cluster V might be judicious for crossing purpose.

\section{References}

Ahmed, M. S., Akter, K., Khalequzzaman, M., Rashid, E. S. M. H. and Bashar, M. K. 2010. Diversity analysis in Boro rice (Oryza sativa L.) accessions. Bangladesh Journal of Agricultural Research, 35(1): 29-36.

Akter, N., Islam, M. Z., Siddique, M. A., Chakrabarty, T., Khalequzzaman, M. and Chowdhury, M.A. Z. 2016. Genetic diversity of Boro rice (Oryza sativa L.) landraces in Bangladesh. Bangladesh Journal of Plant Breeding and Genetics, 29(2): 33-40.

Akter, N., Begum, H., Islam, M. Z., Siddique, M. A. and Khalequzzaman, M. 2018 .Genetic diversity in Aus rice (Oryza sativa L.) genotypes of Bangladesh. Bangladesh Journal of Agricultural Research, 43(2): 253-266.

Akter, N., Khalequzzaman, M., Islam, M. Z., Mamun, M. A. A. and Chowdhury, M. A. Z. 2018. Genetic variability and character association of quantitative traits in Jhum rice genotypes. SAARC Journal of Agriculture, 16(1): 193-203.

Alvarado, G., Marco, L., Mateo, V., Angela, P., Francisco, R., Juan, B. and Jose, C. 2015. "META-R (Multi Environment Trail Analysis with $\mathrm{R}$ for Windows) Version 6.03", hdl:11529/10201, CIMMYT Research Data \& Software Repository Network, V21.

Allam, C. R., Jaiswal, H. K. and Qamar, A. 2015. Character association and path analysis studies of yield and quality parameters in basmati rice (Oryza sativa L.). The Bioscan, 9(4): 1733-1737.

Amarawathi, Y., Singh, R., Singh, A. K., Singh, V. P, Mohapatra, T., Sharma, T. R. and Singh, N. 2008. Mapping of quantitative trait loci for basmati quality traits in rice (Oryza sativa L.). Molecular Breeding, 21: 49-65. 
BBS (Bangladesh Bureau of Statistics). 2016. Statistical Year Book of Bangladesh 2016. Bangladesh Bureau of Statistics Division, Ministry of Planning, Govt. of the People's Republic of Bangladesh, Dhaka.

Burton, G. W. and Devane, E. H. 1953. Estimating heritability in tall fescue (Festuca arundinaceae) from replicated clonal material. Agronomy Journal, 45(10): 478-481.

Chakravorty, A.,Ghosh, P. D. and Sahu, P. K. 2013. Multivariate analysis of phenotypic diversity of landraces of rice of West Bengal. American Journal of Experimental Agriculture, 3(1): 110-123.

Comstock, R., Robinson, H. and Gowen, J. 1952. Estimation of average dominance of genes. Heterosis, 494-516.

Hasan, M. J., Kulsum, M. U., Hoque, N., Miah, M. A. and Azam, F. A. M. S. 2010. Genetic variability, correlation and path coefficient analysis in some restorer lines of hybrid rice (Oryza sativa L.). Ecofriendly Agricultural Journal, 3(5): 222226.

Hasan, M. J., Kulsum, M. U., Akter, A., Masuduzzaman, A. S. M. and Ramesha, M. S. 2011. Genetic variability and character association for agronomic traits in hybrid rice (Oryza Sativa L). Bangladesh Journal of Plant Breeding and Genetics, 24(1): 45-51.

Islam, M. Z., Siddique, M. A., Rashid, E. S. M. H., Ahmed, M. S. and Khalequzzaman, M.. 2014. Genetic Diversity in Sadajira rice (Oryza sativa L.) germplasm. The Agriculturists. 2(1): 26-32.

Islam, M. Z., Khalequzzaman, M., Bashar, M. K., Ivy, N. A., Haque, M. M. and Mian, M. A. K. 2016. Variability assessment of aromatic and fine rice germplasm in Bangladesh based on quantitative traits. The Scientific World Journal, 2016: 1-14.

Islam, M. Z., Khalequzzaman, M., Siddique, M. A., Akter, N., Ahmed, M. S. and
Chowdhury, M. A. Z. 2017. Phenotypic characterization of jhum rice (Oryza sativa L.) landraces collected from Rangamati District, Bangladesh. Bangladesh Rice Journal, 21(1): 47-57.

Johnson, H. W., Robinson, H. F. and Comstock, R. E. 1955. Estimation of genetic and environmental variability in soybean. Agronomy Journal, 47: 314-318.

Kumar, S., Chauhan, M. P., Tomar, A., Kasana, R. K. and Kumar, N. 2018. Correlation and path coefficient analysis in rice (Oryza sativa L.). The Pharma Innovation Journal, 7(6): 20-26.

Mazid, M. S., Rafii, M. Y., Hanafi, M. M., Rahim, H. A. and Latif, M. A. 2013. Genetic variation, heritability, divergence and biomass accumulation of rice genotypes resistant to bacterial blight revealed by quantitative traits and ISSR markers. Physiologia Plantarum, 149(3): 432-447.

Mannan M. A., Bhuiya, M. S. U., Akhand, M. I. M. and Zaman, M. M. 2012. Growth and Yield of Basmati and Traditional Aromatic Rice As Influenced By Water Stress and Nitrogen Level. Journal of Science Foundation, 10(2): 52-62.

Oad, F. C., Samo, M. A., Hassan, Z. U., Pompe, S. C. and Oad, N. L. 2002. Correlation and path analysis of quantitative characters of rice ratoon cultivars and advance lines. International Agricultural Biology, 4: 204-07.

Osman, K. A., Mustafa, A. M., Ali, F., Yonglain, Z. and Fazhan, Q. 2012. "Genetic variability for yield and related attributes of upland rice genotypes in semi arid zone (Sudan)," African Journal of Agricultural Research, 7(33): 4613-4619.

Pandey, P. and Anurag, P. J. 2010. Estimation of genetic parameters in indigenous rice. Advances in Agriculture \& Botanics, 2(1): 79-84. 
Sabesan, T., Suresh, R. and Saravanan, K. 2009. Genetic variability and correlation for yield and grain quality characters of rice grown in coastal saline low land of Tamil Nadu. Electronic Journal of Plant Breeding, 1: 56-59.

Salgotra, R. K., Bhat, J. A., Gupta, B. B. and Sharma, S. 2017. Determination of genetic relationship among basmati and non- basmati rice (Oryza sativa L.) genotypes from North-West Himalayas using microsatellite markers. Indian Journal of Biotechnology, 16: 68-75.
Siddique, M. A., Khalequzzaman, M., Islam, M. Z., Ahmed, M. S. and Rashid, E. S. M. H. 2013. Genetic diversity in local Boro rice (Oryza sativa L.) genotypes of Bangladesh. Bangladesh Journal of Plant Breeding and Genetics, 26(1): 19-24.

Yoshihashi T. 2005. Does Drought Condition Induce the Aroma Quality of Aromatic Rice. Japan Intl. Res. Center for Agril. Sci. (JIRCAS). Food Sci. Divn. News Letter for Intl. Collaboration. no. 45. Japan. p.4 